\title{
MORPHOLOGICAL EFFECT OF ANTISERUM TO LUTEINIZING HORMONE ON EARLY PREGNANCY IN MICE
}

\author{
SAFIA R. MUNSHI AND O. NILSSON \\ Institute for Research in Reproduction (ICMR), Parel, Bombay 12, India, and \\ Institute of Human Anatomy, S 75220 Uppsala, Sweden
}

(Received 14th September 1972)

Rabbit antiserum to ovine $\mathrm{LH}$ is capable of neutralizing the endogenous activity of mouse LH (Munshi \& Rao, 1967). Administration to mated female mice on any one day from Days 2 to 7 after mating results in the inhibition of pregnancy. Since this inhibition can be overcome only by the continuous administration of progesterone, it has been suggested that the antiserum blocks pregnancy by inhibiting progesterone synthesis by the corpus luteum (Munshi, Purandare \& Rao, 1972). These studies, however, do not indicate at what stage pregnancy is affected.

Since the various stages of pregnancy differ morphologically, microscopy has been used to examine the early stages of pregnancy in mice injected with antiserum to LH in order to find out when pregnancy is affected.

Random-bred albino mice of the NMRI strain were used. Females were placed with males overnight and examined for the presence of a vaginal plug the next morning. The day on which a vaginal plug was seen was taken as Day 1 of pregnancy.

Fertilized mice were injected subcutaneously with $0.2 \mathrm{ml} \mathrm{LH}$ antiserum on Day 2, 3 or 4 after mating. To facilitate detection of early implantation sites, Pontamine Blue was injected intravenously $10 \mathrm{~min}$ before autopsy. Mice were prepared by an aortic perfusion of $2.5 \%$ glutaraldehyde in phosphate buffer, $\mathrm{pH}$ $7 \cdot 2$, on Days 5 to 8 and Day 10 of pregnancy. Both implantation sites and small pieces of endometrium between the implantation sites were taken for microscopy. The specimens were post-fixed in a buffered solution of osmium tetroxide and embedded in Epon for sectioning. Sections, 1 to $2 \mu \mathrm{m}$ thick, were stained in $2 \%$ Toluidine Blue in a $1 \%$ aqueous solution of borax for examination under the light microscope.

Mice treated with antiserum and perfused on Day 6 or 7 of pregnancy showed a positive Pontamine Blue reaction indicating that implantation had taken place. The morphology displayed by the treated animals was similar to that seen in control mice until Day 7 (Pl. 1, Figs 1 and 2), but animals perfused on Days 8 and 10 of pregnancy showed extensive haemorrhage which resulted in the termination of pregnancy.

These results indicate that a single injection of $\mathrm{LH}$ antiserum, although capable of inhibiting pregnancy in the mouse (Munshi, Purandare \& Rao, 1972) did not prevent the blastocysts from implanting, nor did such treatment 
block the shift in mitotic activity from epithelial to stromal cells in the uterus of mice on Day 4 of pregnancy (S. R. Munshi, T. V. Purandare and S. S. Rao, unpublished results). This change in the pattern of cell division in normal pregnancy (Finn \& Martin, 1967) is brought about by the secretion of progesterone (Martin \& Finn, 1968; Finn \& Martin, 1969) and is considered to be an important factor in the preparation of the uterus for implantation (Finn, Martin \& Carter, 1969).

Neutralization of pituitary LH during the preimplantation stage of pregnancy, which should impede the production of progesterone, fails to affect both implantation of blastocysts and uterine cell division in the mouse. This delayed action of the injection of antiserum may be due to the persistence of an effect of progesterone in the endometrium although the secretion of progesterone by the ovary has ceased (Bergström \& Nilsson, 1972; Deanesly, 1972). But it may also be that the antiserum takes some time to block the synthetic processes in the ovary, or that the drug only partially suppresses progesterone secretion and that later this effect becomes apparent if the demands for the hormone by the developing conceptus increase.

Ovine LH used for the preparation of the antiserum was a gift of the Endocrinology Study Section, National Institute of Health, Bethesda. The work was supported by the Ford Foundation (Fellowship to Dr S. R. Munshi) and by the Swedish Medical Research Council (Project No. 12X-70). The technical assistance of Mrs Marianne Ljungkvist and Miss Barbro Pettersson is gratefully acknowledged.

\section{REFERENCES}

Bergström, S. \& NiLsson, O. (1972) Ultrastructural response of blastocysts and uterine epithelium to progesterone deprivation during delayed implantation in mice. 7 . Endocr. 55, 217.

DeanesLy, R. (1972) Retarded embryonic development and pregnancy termination in ovariectomized guinea-pigs: progesterone deficiency and decidual collapse. F. Reprod. Fert. 28, 241.

Finn, G. A. \& Martin, L. (1967) Patterns of cell division in the mouse uterus during early pregnancy. 7. Endocr. 39, 593.

FinN, C. A. \& MARTin, L. (1969) Hormone secretion during early pregnancy in the mouse. F. Endocr. $45,57$.

Finn, C. A., Martin, L. \& Carter, J. (1969) A refractory period following oestrogenic stimulation of cell division in the mouse uterus. $\mathcal{F}$. Endocr. 44, 121 .

Martin, L. \& FinN, C. A. (1968) Hormonal regulation of cell division in epithelial and connective tissues of the mouse uterus. F. Endocr., 41, 363.

Munshi, S. R., Purandare, T. V. \& Rao, S. S. (1972) Effect of antiserum to ovine luteinizing hormone on corpus luteum function in mice. J. Reprod. Fert. 30, 7.

Munshi, S. R. \& RAo, S. S. (1967) Biological specificity of antigens present in ovine luteinizing hormone. Indian fnl exp. Biol. 5, 135. 


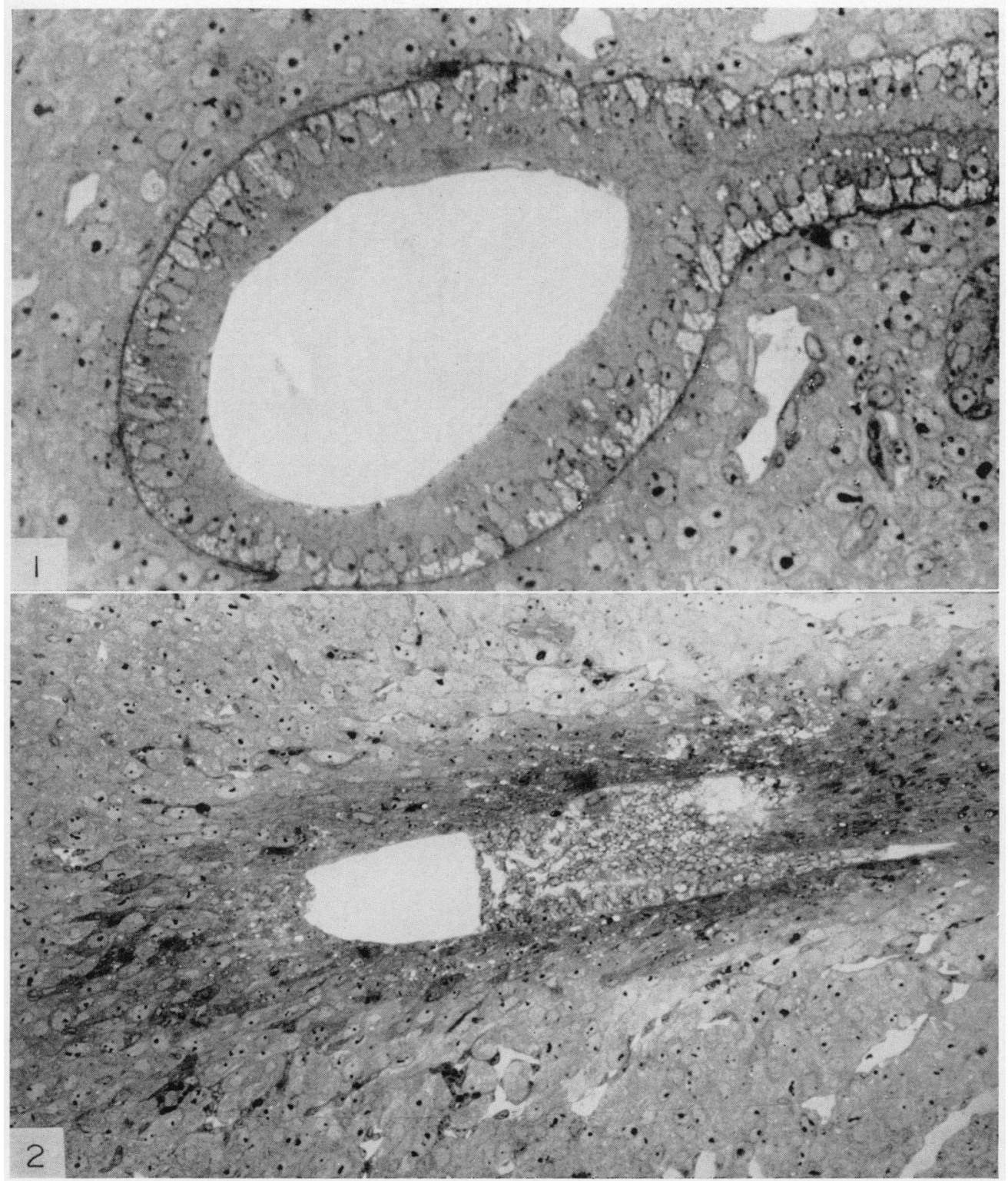

FIG. 1. Implantation site, Day 4, in a mouse injected with rabbit anti-ovine LH serum on 1)ay 2. The blastocyst is seen closely surrounded by the uterine epithelium. To the right, the attachment reaction of the uterine epithelium is observed to have obliterated the uterine lumen. This implantation site has a normal appearance. $\times 500$.

Fici. 2. Implantation site, Day 6 , of a mouse injected with rabbit anti-ovine $\mathrm{LH}$ serum on I) ay 2. This implantation site has a normal appearance. $\times 300$. 